\title{
Predicting Condom Use: A Comparison of the Theory of Reasoned Action, the Theory of Planned Behavior and an Extended Model of TPB
}

\author{
Alexandra Isabel Cabral da Silva Gomes ${ }^{1}$ \\ Maria Cristina Salgado Nunes \\ Research Centre for Spatial and Organizational Psychology \\ Universidade do Algarve
}

\begin{abstract}
It was our goal to give a contribution to the prediction of condom use using socio-cognitive models, comparing classic theories to an extended model. A cross-sectional study was conducted using a questionnaire of self-reported measures. From the students who agreed to participate in the study, 140 were eligible for the full study. A confirmatory analysis was used to assess the predictive value of the researched model.

The model tested had slightly better fit indexes and predictive value than classic Theories of Reasoned Action and Planned Behaviour. Although the results found, discussion continues to understand the gap between intention and behaviour, as further investigation is necessary to fully understand the reasons for condom use inconsistency.
\end{abstract}

Keywords: HIV/AIDS, Theory of Reasoned Action, Theory of Planned Action, Condom use extended model

\section{Predizendo o Uso de Preservativo: Uma Comparação entre a Teoria da Ação Racionalizada, a Teoria do Comportamento Planejado (TCP) e um Modelo Estendido de TCP}

\begin{abstract}
RESUMO - Tivemos como objetivo contribuir para a predição do uso de preservativo utilizando modelos sociocognitivos, comparando teorias clássicas a um modelo estendido. Um estudo transversal foi conduzido com o uso de questionário de auto-relato. Entre os estudantes que aceitaram participar do estudo, 140 mostraram-se elegíveis a participar do estudo em sua totalidade. Uma análise confirmatória foi utilizada para acessar o valor preditivo do modelo pesquisado. O modelo testado apresentou melhores índices de ajustamento e valor preditivo que as clássicas teorias da Ação Racionalizada e do Comportamento Planejado. Apesar dos resultados obtidos, continua a discussão para entender as discrepâncias entre intenção e comportamento, assim como são necessários mais estudos que permitam melhor compreender a inconsistência nas razões para o uso de preservativos.
\end{abstract}

Palavras-Chave: HIV/Aids, Teoria da Ação Racionalizada, Teoria do Comportamento Planejado, Modelo estendido do uso de preservativo

In Portugal, HIV cases increase every year among the heterosexual population, with young adults being particularly affected (Instituto Nacional de Saúde, 2016), due to inconsistent use of condoms. In order to design and implement interventions capable of preventing the increase of HIV infection and other sexually transmitted infections, we should know which variables affect condom use behaviour.

The Theory of Reasoned Action (TRA; Fishbein \& Ajzen, 1975) and its extension, the Theory of Planned Behaviour (TPB; Ajzen \& Madden, 1986), have been widely used in the health behaviour investigation, including condom use, among several samples (Andrew et al., 2016; Armitage \& Conner, 2001; Noar \& Zimmerman, 2005).

For both models, the best indicator of behaviour is intention, which is predicted by the attitude towards behaviour and by the subjective norm. Problems with the volitional nature of behaviour, such as condom use, lead to

1 Address for correspondence: Universidade do Algarve, Campus de Gambelas, Edf. 1, Faculdade de Ciências Humanas e Sociais, Gambelas, Faro, Portugal. CEP: 8005-139.E-mail: asgomes@ualg.pt the introduction of the perceived behavioural control (PBC) on TPB model (Ajzen \& Madden, 1986).

Both theories have achieved moderate results when it comes to explaining condom use behaviour through condom use intention, and it was observed that people are more likely to use condoms if they already have a prior intent to do so (Albarracín, Johnson, Fishbein, \& Muellerleile, 2001). However, Muñoz-Silva, Sánchez-García, Nunes and Martins (2007) observed that, due to perceived behavioural control, the TPB model is more effective in explaining condom use than the TRA version. The authors suggest the use of other predictors in order to increase the model's efficacy further. Nevertheless, the positive impact of $\mathrm{PBC}$ is not consistent among literature. More recently, Espada et al. (2016) compared TPB and IMB in their efficacy to predict condom and observed that $\mathrm{PBC}$ has had no effect in predicting frequency of condom use and has pointed to the importance to test integrative models that include personal, contextual, environmental and social factors. 
Visser and Smith (2001) observed that for those who sometimes use a condom, the most important determinants were the characteristics of the interaction between the sexual partners and the state-like characteristics of the individuals concerned. Beadnell et al. (2008) also noted that psychological distress, the risk of contracting sexually transmitted diseases, and male gender-role attitudes might increase the predictive value of the models. Participants' age, sex and religiosity may also have an impact on condom use intention and behaviour (Ajzen \& Manstead, 2007). Condom use inconsistency or non-use was associated with older college students (Adefuye, Abiona, Balogun, \& LukoboDurrel, 2009) and men (Galvez-Buccollini, Delea, Herrera, Gilman, \& Paz-Soldan, 2009; Shearer, Hosterman, Gillen, \& Lefkowitz, 2005). A more positive attitude towards condoms is associated with greater religiosity (McCree, Wingood, DiClemente, Davies, \& Harrington, 2003). The number of sexual partners and the existence of a steady partner should also be considered (Bogart et al., 2005).

Self-esteem also influences aspects of health behaviour. Students with low self-esteem consume more alcohol, have more sexual partners and are at a higher risk of contracting HIV (Gullete \& Lyons, 2006). Women with low self-esteem and negative mood-states were also more likely to report engagement in unprotected sex (MacDonald \& Martineau, 2002). Low self-esteem directly influences rates of sexual activity without protection (Ethier et al., 2006).

Sexual fulfilment is negatively related to condom use (Sunmola, 2005). One of the major barriers to condom use is the accompanying lack of sensation and consequential lack of sexual contentment (Kaneko, 2007). More recently, He, Hensel, Harezlak, and Fortenberry (2016) observed that relationship and sexual satisfaction decreases condom use frequency, especially among women.
Heuristics also influence condom use. To believe that "monogamous sex is safe sex" negatively influence the decision to use a condom (Ayala, Rivas, \& Bingham, 2005). Moreover, to believe that "knowing your partner makes him or her safe" was also negatively associated with condom use and pregnancy prevention behaviours (Thornburn, Harvey, \& Ryan, 2005).

Some studies have pointed out the importance of parental communication. A satisfactory mother-daughter discussion about the topic was associated with higher rates of protected sexual activity (Hutchinson, Jemmott, Jemmott, Braverman, \& Fong, 2003). Moreover, boys with a greater ability to communicate with their parents used condoms more consistently (Halpern-Felsher, Kropp, Boyer, Tschann, \& Ellen, 2004). Birth control use was also enhanced by talking to parents about sexual behaviour (Aspy et al., 2007). Adolescents were more likely to use condoms when parental communication about sex had happened prior to their first experience of sexual intercourse (Clawson \& Reese-Weber, 2003).

Finally, the use of substances which can alter conscience states and behaviour was also related with condom use inconsistency. Alcohol consumption has a negative effect on condom use (Galvez-Buccollini et al., 2009; Walsh, Fielder, Carey, \& Carey, 2013).

Due to the need to improve socio-cognitive models to explain and predict condom use, and to the inconsistency observed in meta-analysis conducted on condom use predictive models, in this study we intended to extend the TPB model (Figure 1) including other variables in order to increase its predictive value. Fit indexes were examined by using a pathway analysis. In particular, a regression analysis was conducted to test if condom use intention and behaviour could be predicted. A cross-sectional study with self-reporting measures was, therefore, developed in order to assess this model's predictive value.

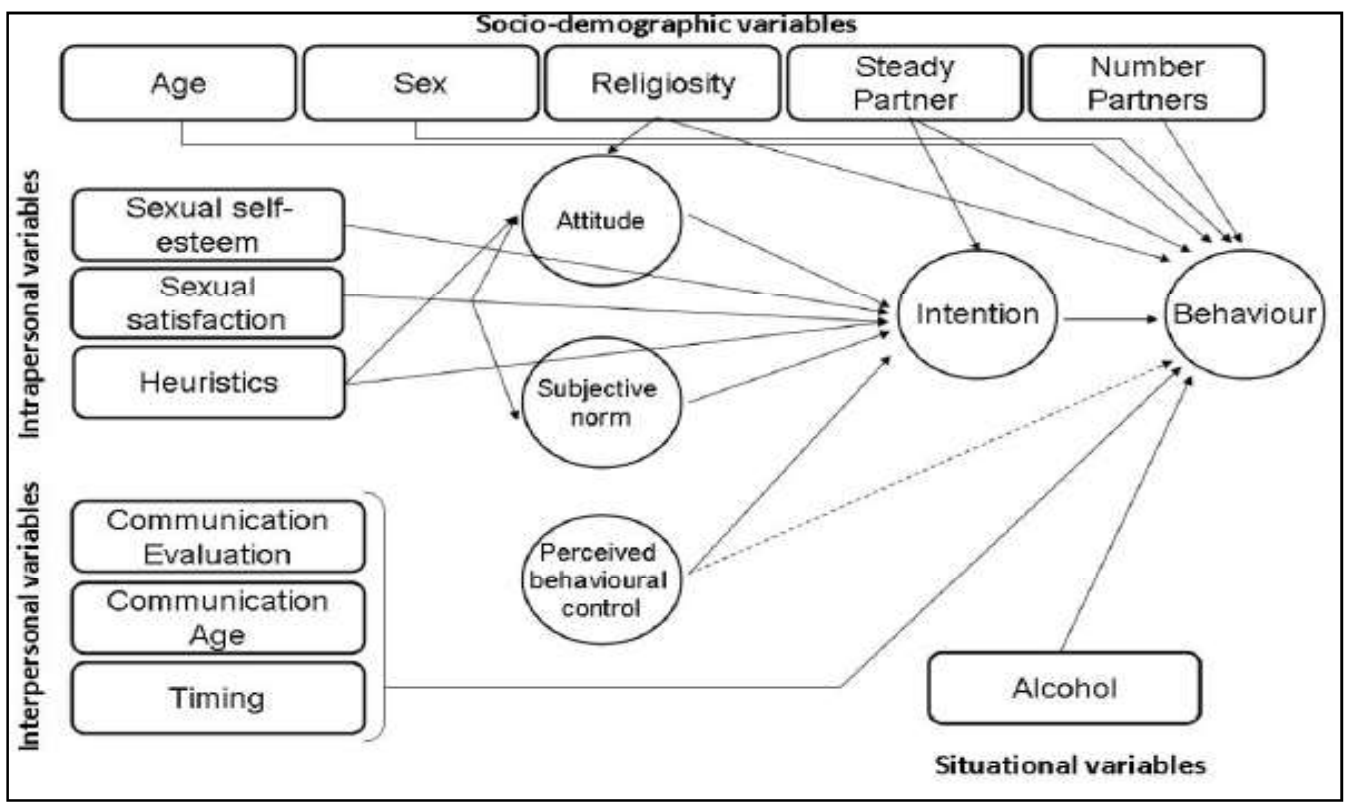

Figure 1. Extended model Direct relations on the prediction of intention and condom use behaviour 


\section{Methods}

\section{Participants}

A hundred and seventy-six (176) students were approached to fill in the questionnaire. The exclusion criteria were age (between 18 and 25 years old), sexual orientation (only heterosexual individuals were considered) and sexual history (subjects had to already had sexual intercourse). 140 students from University of Algarve (Portugal) met the criteria, with a mean age of 20.79 years; $64 \%$ were female.

\section{Measures}

Table 1 describes the variables measured along with a sample item. Reliability and descriptive measures are presented.

Intrapersonal variables. Attitude towards condoms was measured by Brown's Attitude towards Condom Scale (Brown, 1984). The original five point scale was extended to include 1 (never) to 7 (always). Heuristics were assessed using three sentences that evaluated beliefs about HIV.

Perceived behavioural control was assessed by the Sexual Risk Behaviour Beliefs and Self-Efficacy Scales (BasenEngquist, 1996).
Sexual satisfaction and sexual self-esteem were items of the Multi-dimensional Sexual Self-Concept Questionnaire (Snell, 1995). A seven point scale, from 1 (never) to 7 (always) was used.

The subjective norm focused on the perception of the pressure a partner exerted to use or not condoms during sexual intercourse. A seven point scale, from 1 (never) to 7 (always) was used.

Interpersonal variables. Communication was evaluated with a single question and one out of three answers was possible: 0 for non-existent; 1 for unsatisfied; and 2 for totally satisfied. The age at which the communication started was assessed by an open-question. Finally, timing was calculated using Clawson and Reese-Weber's (2003) recommended approach. If parents communicated about sex before the first experience of sexual intercourse, it was considered to be on time. In contrast, if the topic had arisen after sex had taken place, it was regarded as being out of time.

Situational variables. Three different situations in which alcohol could be consumed were assessed: daily, socially (hanging out with friends), and relaxing before a sexual encounter. A seven point scale, from 1 (never) to 7 (always) was used.

Intention and behaviour of condom use. They were assessed by one question each. A seven point scale, from 1 (never) to 7 (always) was used.

Table 1. Measures descriptive statistics

\begin{tabular}{|c|c|c|c|c|}
\hline Variable/measure & $\begin{array}{l}\text { Number } \\
\text { of Items }\end{array}$ & Sample & Reliability & Descriptive measures \\
\hline Age & 1 & (open question) & 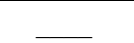 & $\mathrm{M}=20.79 ; \mathrm{SD}=1.980$ \\
\hline Age fist intercourse & 1 & (open question) & & $\mathrm{M}=16.88 ; \mathrm{SD}=1.801$ \\
\hline Partner's age at first intercourse & 1 & (open question) & & $\mathrm{M}=18.20 ; \mathrm{SD}=2.448$ \\
\hline Number of partners & 1 & (open question) & & $\mathrm{M}=3.77 ; \mathrm{SD}=4.48$ \\
\hline Steady partner & 1 & Do you have a steady partner, at the moment? & & Mode $=$ yes \\
\hline $\begin{array}{l}\text { Number of partners in the last } 3 \\
\text { months }\end{array}$ & 1 & How many partners did you have in the last 3 months? & & $\mathrm{M}=1.09 ; \mathrm{SD}=0.935$ \\
\hline Religion & 1 & (open question) & 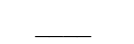 & Mode $=$ Catholic \\
\hline Religiosity & 1 & In what extent do you consider yourself as a religious person? & $\underline{-}$ & $\mathrm{M}=3.14 ; \mathrm{SD}=1.581$ \\
\hline Attitudes & 40 & $\begin{array}{l}\text { I would have no objection if my partner suggested that we } \\
\text { used a condom. }\end{array}$ & $\alpha=0.77$ & $\mathrm{M}=4.87 ; \mathrm{SD}=0.967$ \\
\hline HIV heuristics & 3 & $\begin{array}{l}\text { If you love and trust someone, you don't have to worry about } \\
\text { getting HIV from them }\end{array}$ & - & - \\
\hline Sexual self-esteem & 5 & $\begin{array}{l}\text { I derive a sense of self-pride from the way I handle my own } \\
\text { sexual needs and desires }\end{array}$ & $\alpha=0.88$ & $\mathrm{M}=5.45 ; \mathrm{SD}=1.084$ \\
\hline Sexual satisfaction & 5 & I am satisfied with the way my sexual needs are being met & $\alpha=0.92$ & $\mathrm{M}=5.33 ; \mathrm{SD}=1.310$ \\
\hline Perceived Behavioural Control & 3 & $\begin{array}{l}\text { If you decide to have sex, how sure are you that you would } \\
\text { have a condom with you when you needed it? }\end{array}$ & $\alpha=0.59$ & $\mathrm{M}=5.43 ; \mathrm{SD}=1.084$ \\
\hline Subjective norm & 1 & $\begin{array}{l}\text { To what extent do you feel that it is your partner who decides } \\
\text { if you both use a condom in a sexual relationship? }\end{array}$ & - & $\mathrm{M}=5.32 ; \mathrm{SD}=1.162$ \\
\hline Condom use & 1 & How often you use condoms in your sexual intercourse? & {[} & $\mathrm{M}=4.99 ; \mathrm{SD}=1.966$ \\
\hline Condom use intention & 1 & $\begin{array}{l}\text { In what extent do you want to always use condoms in your } \\
\text { sexual intercourse? }\end{array}$ & 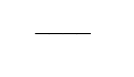 & $\mathrm{M}=5.21 ; \mathrm{SD}=2.071$ \\
\hline Communication with parents & 1 & $\begin{array}{l}\text { In what extent you are satisfied with the parent-children } \\
\text { discussions about sex? }\end{array}$ & 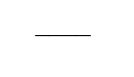 & 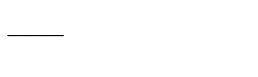 \\
\hline Alcohol consumption & 3 & $\begin{array}{l}\text { In what extent do you drink alcoholic drinks with the purpose } \\
\text { to relax before a sexual encounter? }\end{array}$ & $\alpha=0.94$ & $\mathrm{M}=2.53 ; \mathrm{SD}=2.134$ \\
\hline
\end{tabular}




\section{Procedure}

Permission to collect data from students was sought from the University of Algarve. The students were approached in their classroom and their informed consent was requested. To ensure privacy and confidentiality, a sealed box was placed in the classroom into which the completed questionnaires were placed by the students themselves.

Data was introduced into the SPSS v.17 in respect of the descriptive measures. AMOS 7 was used to conduct the pathway analysis.

\section{Results}

\section{The Models' Fit}

The fit indexes of the three models, the TRA, TPB and the extended version, were tested using a pathway analysis. To compare the adjustment of the data to the theoretical model, several statistical fit indexes were used. The relative chi-square statistic, as an absolute fit, was applied, assuming that the minimum discrepancy degree between chi-square and freedom degrees should be less than three to be considered a reasonable fit (Carmines \& McIver, 1983), but should preferably approach or be below two (Hoelter, 1983). The CFI, or comparative fit index (Bentler, 1990), and the GFI, or goodness of fit (Jöreskog \& Sörbom, 1986), were also used, with values close to one indicating a good fit. The standardized root mean-square residual (SRMR) and the root square-mean error of approximation (RMSEA) were used as well. For the former, smaller values are indicative of a good fit: those below 0.05 represent a good fit, below 0.08 a reasonable fit, below 0.10 a poor fit, and above 0.10 equates to an unacceptable fit (Browne \& Cudeck, 1993). Similarly, the standardized root square-mean residual should have values below 0.05 .

Table 2 summarizes the fit results of the TRA, the TPB and the extended model.
In all of the three models, the discrepancies between the data and the theory were significant $(p<0.050)$. The TRA version has a high degree of discrepancy, with the goodness of fit and the comparative fit index being low. Moreover, both the residual error (SRMR) and the approximation error (RMSEA) were well above the levels considered to be a plausible fit.

The TPB model had a good fit according to the GFI, CFI and SRMR. However, the discrepancy, provided by the chisquare statistic and degrees of freedom, is higher than five, and the RMSEA $(<0.050)$ also failed to indicate a good fit.

The extended TPB model had a good discrepancy level, acceptable GFI and CFI measures of fit, and a reasonable RMSEA. According to these measures, we can thus report that the extended TPB model is a plausible fit for the data used.

\section{The Models' Predictive Value}

The predictive value of the three models was assessed by the regression weights.

When comparing the TRA and the TPB, the latter seems to have a better predictive value (table 3 ). The forecasting of intentions through the use of the attitude variable and subjective norm is increased by adding perceived behavioural control to the model. Moreover, the predictive value of condom use intention over condom use behaviour is also enhanced by adding the perceived behavioural control factor.

The predictive value of the extended model is presented in table 4.

It was assumed that attitude was predicted by religiosity and heuristics. In fact, only $7.9 \%$ of attitude variance was explained by those variables. However, the individual regression weight was not significant.

The predictive value of attitude and the subjective norm increased when the variable of having a steady partner, which had a greater weight than both, was introduced. Perceived behavioural control was not, however, significant

Table 2. Theory of Reasoned Action, Theory of Planned Behaviour and Extended Model Measures descriptive statistics

\begin{tabular}{lcccc}
\hline & $\chi 2 /(\mathrm{df})$ & GFI & CFI & SRMR \\
\hline TRA & $46.349 / 2=23.175^{*}$ & 0.175 & 0.642 & 0.0636 \\
TPB & $21.761 / 2=10.710^{*}$ & 0.946 & 0.932 & 0.399 \\
Extended model & $195.638 / 123=1.591^{*}$ & 0.880 & 0.887 & 0.246 \\
\hline Note. ${ }^{*} p<0.001 ; \chi 2 /(\mathrm{df})-$ Chi-square statistic and overall fit ; GFI - Goodness of fit index; CFI - Comparative fit index; RMR - Root mean-square residual; RMSEA - Root
\end{tabular}
mean-square error of approximation

Table 3. The predictive value of the TRA and TPB

\begin{tabular}{llcccc}
\hline & \multicolumn{1}{c}{ Exogenous } & $\boldsymbol{\beta}$ & $\boldsymbol{R}^{2}$ & Endogenous & \multicolumn{1}{c}{$\boldsymbol{\boldsymbol { R } ^ { 2 }}$} \\
\hline TRA & Attitude & $0.310^{* * *}$ & $17.5 \% * * *$ & Intention & $0.878^{* * *}$ \\
& Subjective Norm & $0.198^{*}$ & & & \\
\hline TPB & Attitude & $0.288^{* *}$ & $19.2 \% * * *$ & Intention & $0.851 * * *$ \\
& Subjective Norm & $0.166^{*}$ & & PCB & $0.105 *$ \\
& PBC & $0.140 \mathrm{~ns}$ & & & \\
\hline
\end{tabular}

Note. ${ }^{* * *} p<0.000 ; * * p<0.010 ; * p<0.050 ; \mathrm{ns}$ - non significant; TRA - Theory of Reasoned Action; TPB - Theory of Planned Behaviour; PBC - Perceived Behavioural Control; $\beta$ - regression weights; R2 - Square Correlation; Method used in the regression analysis: Enter 


\begin{tabular}{|c|c|c|c|c|c|c|c|c|c|}
\hline & \multicolumn{3}{|c|}{ Variables predicting attitude } & \multicolumn{3}{|c|}{ Variables predicting intention } & \multicolumn{3}{|c|}{ Variables predicting condom use } \\
\hline & & $\beta$ & $R^{2}$ & & $\beta$ & $R^{2}$ & & $\beta$ & $R^{2}$ \\
\hline \multirow{11}{*}{$\begin{array}{c}\text { Extended } \\
\text { model }\end{array}$} & & & & Attitude & $0.270 * *$ & & Intention & $0.794 * * *$ & \\
\hline & & & & Subjective Norm & $0.186^{*}$ & & Com. Evaluation & $-0.031 \mathrm{~ns}$ & \\
\hline & Religiosity & 0.159 & & PBC & $0,141 \mathrm{~ns}$ & & Com. Age & $0.064 \mathrm{~ns}$ & \\
\hline & Heuristic1 & -0.162 & & Sexual satisfaction & $-0.085 \mathrm{~ns}$ & & Timing & $-0.088 \mathrm{~ns}$ & \\
\hline & Heuristic2 & -0.118 & & Sexual self-esteem & $-0.054 \mathrm{~ns}$ & & Age & $-0.056 \mathrm{~ns}$ & \\
\hline & Heuristic3 & 0.094 & $7,9 \%$ & Heuristic1 & $-0.049 \mathrm{~ns}$ & $33,2 \%$ & Sex & $-0.025 \mathrm{~ns}$ & $80,6 \%$ \\
\hline & & & & Heuristic2 & $0.106 \mathrm{~ns}$ & & Number of partners & $-0.040 \mathrm{~ns}$ & \\
\hline & & & & Heuristic3 & $0.019 \mathrm{~ns}$ & & Steady partner & $0.070 \mathrm{~ns}$ & \\
\hline & & & & Steady partner & $0.284 *$ & & Alcohol & $-0.095^{*}$ & \\
\hline & & & & & & & $\mathrm{PBC}$ & $0.131 * *$ & \\
\hline & & & & & & & Religiosity & $-0.024 \mathrm{~ns}$ & \\
\hline
\end{tabular}

Note. $\mathrm{p}<0.000 ;{ }^{*} \mathrm{p}<0.010 ;{ }^{*} \mathrm{p}<0.050 ; \mathrm{ns}$ - non significant; TPB - Theory of Planned Behaviour; PBC - Perceived Behavioural Control; $\beta$ - regression weights; R2 - Square Correlation; Method used in the regression analysis: Enter

individually in this proposed step of the extended model. Likewise, all of the other contributions were not significant in terms of the explanation of condom use intention variance.

However, compared with the TRA and TPB models, we did produce a better approach with which to predict condom use intention.

Condom use behaviour continues to be mainly predicted by intention and perceived behavioural control, with a slight improvement in the measure being noted after the introduction of the alcohol consumption variable.

\section{Discussion}

The present research aims was to assess the predictive value and data fit of an extended Theory of Planned Behaviour model, comparing it to the original TRA and TPB versions.

\section{Fit and Predictive Value of TRA and TPB}

The results of the confirmatory analysis enabled us to observe that the TPB model surpasses the TRA version; the fit indexes are better in the TPB and it also has a better predictive value of condom use intention and behaviour. The introduction of perceived behavioural control has enhanced the predictive value of the TPB model when it comes to condom use behaviour.

In both models, attitude was a better predictor of condom use intention than the subjective norm, a finding that is consistent with the literature (Armitage \& Conner, 2001; Beadnell et al., 2008; Bennett \& Bozionelos, 2000).

In this study the introduction of perceived behavioural control improved the predictive value of both models. However, this enhancement was not statistically significant. Perceived behavioural control was also the variable with less weight when it came to the prediction of condom use behaviour. According to the meta-analysis of condom use, the influence of perceived behavioural control was moderate and its direct impact was considered to be minimal (Albarracín et al., 2001). Both intention and perceptions of behavioural control can make significant contributions to the prediction of behaviour, but in any given application one may be more important than the other and, in fact, only one of the two predictors may be needed (Ajzen, 1991).

However, perceived behavioural control was assessed by a self-efficacy measure, and PBC concept implies more than belief of control. It implies actual control over the behaviour. According to Ajzen (2002) a high level of perceived behavioural control should enhance a person's intention to perform the behaviour, and when it is veridical it should also affect the behaviour itself. Nevertheless in this study we don't observe a significant impact over intention, as we would expect, but only over the behaviour.

The self-efficacy measure used asked about the belief of being able to use or to have a condom when needed. We didn't measure the actual control over the situation, which might affect and partially explain the results.

Also, the overall participants had a high mean of intention and condom use, which might hinder the effect of the selfefficacy over the intention. In essence, participants that already use condoms might have a high self-efficacy on using them, and its intention of use may not rely on the ability to use them, but only on the control to perform the behaviour, which we have not measured.

In both TRA and TPB models, participants with the intention to use a condom were more likely to do so, which is consistent with literature (Albarracín et al, 2001; Sheeran \& Orbell, 1998).

\section{Fit and Predictive Value of the Extended Theory of Planned Behaviour}

The extended model included socio-demographic, intrapersonal, interpersonal and situational variables which may have an influence on the attitude towards condoms and condom use (intention and behaviour). This was the approach 
that adjusted better to the data, highlighting the need to include other variables in the socio-cognitive models that are used to assess condom use behaviour.

From the variables that were introduced in the model, the presence of a steady partner and alcohol consumption significantly increased its predictive value.

The existence of a steady partner reduced the intention to use a condom but didn't directly influence condom use behaviour. Mercer et al. (2009) observed a statistical reduction on condom use in couples after 21 days of relationship. This fact points out that individuals might consider a partner steady in less than a month, what might put these individuals at risk, with an average of 3 partners, more than a partner in the last three months, and with an inconsistent condom use. In order to promote safer sex behaviours, the belief of a steady partner should be considered and modified, since steady relations have also been associated with ideas of trust, intimacy and romance, which are responsible for decreasing the odds of using a condom (Camargo \& Bousfield, 2009; Kirkman, Rosenthal \& Smith, 1998).

The existence of a steady partner didn't affect condom use behaviour. This was unexpected, since it was anticipated that this factor would have an impact on both variables (Bogart et al., 2005). This null effect could be attributed to the extremely linear correlation between intention and behaviour, which could have diminished the relative weight of the variable to predict condom use behaviour. The metaanalysis conducted on the issue of condom use evidenced strong but smaller correlations between these variables ( $r \approx 0.44$; Albarracín et al., 2001; Sheeran \& Orbell, 1998). The use of a single question to assess condom use intention and behaviour probably led to this similar result. It is possible that participants tried to be consistent in the answers they gave to both questions, thereby producing analogous responses. A longitudinal study should contour this problem, since it would measure intention and behaviour in different time sets.

The prediction of condom use behaviour when the alcohol consumption variable was introduced is corroborated by some of the results found in the literature (Galvez-Buccollini, 2009). The findings herein, therefore, contribute to the discussion about the influence of alcohol on condom use inconsistency. Alcohol consumption does seem to be linked to the occurrence of several other factors, such as the type of sexual partner and beliefs about the impact of alcohol on sexual disinhibition (LaBrie, Earleywine, Schiffman, Pedersen, \& Marriot, 2005). Since we did evaluate whether alcohol was consumed to facilitate sexual encounters, positive answers may indicate that participants believe that alcohol reduces sexual inhibition. These beliefs should be taken into account when intervention is designed.

All of the other variables in the model failed to predict condom use. However, they may be producing mediation effects through their correlation with the other factors. However it wasn't our goal to assess those relations.

\section{Conclusions}

Our extended TPB model added both a socio-demographic and a situational variable, respectively, having a steady partner and alcohol consumption. The consequence was an increase in the predictive value of the model when compared to the original TRA and TPB versions. The extended model also seems to have medium fit indexes, despite the inadequacy of the overall fit measure. Despite the moderate success of the introduction of the two new variables referred to above, a gap continues to exist between trait-like variables, beliefs, and the intention to use a condom.

Several critiques of this type of model may, therefore, be valuable. Visser and Smith (1999) emphasised how important it is to reach an agreement with the sexual partner as a necessary step to being able to use a condom. When it comes to methodology, correlational research is criticized for being an inappropriate way of analysing causality. Behavioural performance tends to produce perceptions that are supportive of the behaviour. However the correlational tests lead to the misclassification of these perceptions as promoting behaviour, forcing it in the direction proposed by theories (Weinstein, 2007). On the other hand, individual analysis may be contrary to the nature of sexual relationships, since sex is not an individual behaviour, instead being a complex dynamic because of the fact that two people are involved (Joffe, 2002; Kashima, Gallois, \& McCamish, 1993).

Since there is still a gap between individual characteristics and condom use behaviour, further studies are required if we are to reduce the levels of inconsistent condom use and, consequently, the rate at which the HIV infection is being spread.

\section{References}

Adefuye, A. S., Abiona, T. C., Balogun, J. A., \& Lukobo-Durrell, M. (2009). HIV sexual risk behaviors and perception of risk among college students: Implications for planning interventions. BMC Public Health, 9(1), 281. doi:10.1186/1471-2458-9-281

Ajzen, I., \& Madden, T.J. (1986). Prediction of goal-directed behavior: Attitudes, intentions and perceived behavioralcontrol. Journal of Experimental Social Psychology, 22, 453474. doi:10.1016/0022-1031(86)90045-4

Ajzen, I., \& Manstead, A.S.R. (2007). Changing health-related behaviors: An approach based on the theory of planned behaviour. In K. Bos, J. Hwestone, H. Wit., H. Chut, \& M. Stroebe (Eds), The scope of social psychology: Theory and applications (pp. 43-63). New York: Psychology Press.

Ajzen, I. (1991). The Theory of Planned Behavior. Organizational Behavior And Human Decision Processes, 50, 179-211. doi: 10.1016/0749-5978(91)90020-T

Ajzen, I. (2002). Perceived behavioral control, self-efficacy, locus of control, and the Theory of Planned Behavior. Journal of Applied Social Psychology, 32(4), 665-683. doi: 10.1111/ j.1559-1816.2002.tb00236.x

Albarracín, D., Johnson, B. T., Fishbein, M., \& Muellerleile, P.A. (2001). Theories of reasoned action and planned behavior as models of condom use: A meta-analysis. Psychological Bulletin, 127(1), 142-161. doi: 10.1037//0033-2909.127.1.142 
Andrew, B. J., Mullan, B. A., de Wit, J. B. F., Monds, L. A., Todd, J., \& Kothe, E. J. (2016). Does the theory of planned behaviour explain condom use behaviour among men who have sex with men? A meta-analytic review of the literature. AIDS Behavior, 20(12), 2834-2844. doi: 10.1007/s10461-016-1314-0.

Armitage, C., \& Conner, M. (2001). Efficacy of the theory of planned behaviour: A meta-analytic review. British Journal of Social Psychology, 40, 471-499. doi:10.1348/014466601164939

Aspy, C.B., Vesely, S.K., Oman, R.F., Rodine, S., Marshall, L., \& McLeroy, K. (2007). Parental communication and youth sexual behaviour. Journal of Adolescence, 30, 49-466. doi:10.1016/j. adolescence.2006.04.007

Ayala, G., Rivas, D., \& Bingham, T. (2003, July). HIV prevention heuristics and other factors that factors that facilitate heightened HIV risk for latino men who have sex with men in Los Angeles county, 2003 [abstract]. National HIV Prevention Conference, Atlanta, GA.T2-A1502.

Basen-Engquist, K., Mâsse, L., Coyle, K., Kirby, D., Parcel, G., Banspach, S., \& Nodora, J. (1998). Sexual risk behavior beliefs and self-efficacy scales. In G. Davis, W. Yarber, R. Bauserman, G. Schreer, \& S. Davis (Eds), Handbook of sexuality related measures (pp. 541-544). California: Sage Publications.

Beadnell, B., Baker, S. A., Gillmore, M. R., Morrison, D. M., Huang, B., \& Stielstra, S. (2008). The Theory of Reasoned Action and the role of external factors on heterosexual men's monogamy and condom use. Journal of Applied Social Psychology, 38(1), 97-134. doi:10.1111/j.1559-1816.2008.00298.x

Bennett, P., \& Bozionelos, G. (2000). The theory of planned behaviour as predictor of condom use: A narrative review. Psychology, Health \& Medicine, 5(3), 307-326. doi: 10.1080/713690195

Bentler, P.M. (1990). Comparative fit indexes in structural models. Psychological Bulletin, 107, 238-246. doi:10.1037//00332909.107.2.238

Bogart, L. M., Kral, A. H., Scott, A., Anderson, R., Flynn, N., Gilbert, M. L., \& Bluthenthal, R. N. (2005). Condom attitudes and behaviors among injection drug users participating in California syringe exchange programs. AIDS and Behavior, 9(4), 423-432. doi: 10.1007/s10461-005-9014-1

Brown, I.S. (1984). Development of a scale to measure attitude toward the condom as a method of birth control. The Journal of Sex Reseach, 20, 255-263. doi: 10.1080/00224498409551224

Browne, M. W., \& Cudeck, R. (1993). Single-sample crossvalidation indices for covariance structures. Multivariate Behavioral Research, 24, 445-455. doi: http://dx.doi. org/10.1207/s15327906mbr2404_4

Camargo, B. V., \& Bousfield, A. B. (2009). Social representations, risk behaviors and AIDS. The Spanish Journal of Psychology, 12(2), 565-575. link: http://europepmc.org/abstract/MED/19899657/ reload $=0$;jsessionid=3lVEqE7PGkyuz516OdmJ.2

Carmines, E. G., \& McIver, J. P. (1983). An introduction to the analysis of models with unobserved variables. Political Methodology, 9, 51-102. Retrieved from http://www.jstor.org/ stable/25791175

Clawson, C. L., \& Reese-Weber, M. (2003). The amount and timming of parent-adolescent sexual communication as predictor of late adolescent risk-taking behavior. The Journal of Sex Research, 40(3), 256-265. doi:10.1080/00224490309552190
Espada, J., Morales, A., Guillén-Riquelme, A., Ballester, R., \& Orgilés, M. (2016). Predicting condom use in adolescentes: A test of three socio-cognitive models using a structural equation modeling approach. BMC Public Health, 16, 35. doi: 10.1186/ s12889-016-2702-0

Ethier, K. A., Kershaw, T. S., Lewis, J. B., Milan, S., Niccolai, L. M., \& Ickovics, J. R. (2006). Self-esteem, emotional distress and sexual behavior among adolescent females: Inter-relationships and temporal effects. Journal of Adolescent Health, 38, 268-274. doi:10.1016/j.jadohealth.2004.12.010

Farmer, M. A., \& Meston, C. M. (2006). Predictors of condom use self-efficacy in a ethnically diverse university sample. Archives of Sexual Behavior, 35(3), 313-326. doi:10.1007/ s10508-006-9027-5

Fishbein, M., \& Ajzen, I. (1975). Belief, attitude, intention and behavior: An introduction to theory and research. Reading, MA: Addison-Wesley.

Galvez-Buccollini, J. A., Delea, S., Herrera, P. M., Gilman, R. H., \& Paz-Soldan, V. (2009). Sexual behavior and drug consumption among young adults in a shantytown in Lima, Peru. BMC Public Health, 9, 23. doi: 10.1186/1471-2458-9-23

Gullete, D. L., \& Lyons, M. A. (2006). Sensation seeking, selfesteem, and unprotected sex in college students. Journal of the Association of Nurses in AIDS Care, 17(5), 23-31. doi:10.1016/j.jana.2006.07.001

Halpern-Felsher, B., Kropp, R., Boyer, C., Tschann, J., \& Ellen, J. (2004). Adolescents self-efficacy to communicate about sex: Its role in condom attitudes, commitment and use. Adolescence, 39(155), 443-456. Retrieved from http://search.ebscohost. com/login.aspx ?direct $=$ true $\& \mathrm{db}=\mathrm{pbh} \& \mathrm{AN}=15616702 \&$ lang $=$ pt-br\&site $=$ ehost-live

He, F., Hensel, D. J., Harezlak, J., \& Fortenberry, J. D. (2016). Condom use as a function of number of coital events in new relationships. Sexually Transmitted Diseases, 43(2), 67-70. doi: 10.1097/OLQ.0000000000000390

Hoelter, J. W. (1983). The analysis of covariance structures: Goodness-of-fit indices. Sociological Methods and Research, 11, 325-344. doi: 10.1177/0049124183011003003

Hutchinson, M. K., Jemmott, J. B., Jemmott, L. S., Braverman, P., \& Fong, G. T. (2003). The role of mother-daughter sexual risk communication in reducing sexual risk behaviors among urban adolescent females: A prospective study. Journal of Adolescent Health, 33, 98-107. doi:10.1016/S1054-139X(03)00183-6

Instituto Nacional de Saúde. (2016): Infecção VIH/SIDA - A situação em Portugal a 31 de Dezembro de 2015. Lisboa: Ministério da Saúde. Retrieved from https://repositorio. insa.pt/bitstream/10400.18/4101/3/Relat\%C3\%B3rio\%20 VIH_SIDA_2015.pdf.pdf

Joffe, H. (2002). Social representations and health psychology. Social Science Information, 4(4), 559-580. doi:10.1177/0539018402041004004

Jöreskog, K. G., \& Sörbom, D. (1986). LISREL VII: analysis of linear structural relationship by maximum likelihood and least square method. Mooresville: Scientific Software.

Kaneko, N. (2007). Association between condom use and perceived barriers to and self-efficacy of safe sex among young women in Japan. Nursing and Health Sciences, 9, 284-289. doi:10.1111/ j.1442-2018.2007.00338.x 
Kashima, Y., Gallois, C., \& McCamish, M. (1993). The theory of reasoned action and cooperative behaviour: It takes two to use a condom. British Journal of Social Psychology, 32 (3), 227-239.

Kirkman, M., Rosenthal, D., \& Smith, A. M. A. (1998). Adolescent sex and the romantic narrative: Why some young heterosexuals use condoms to prevent pregnancy but not disease. Psychology, Health \& Medicine, 3(4), 355-370. doi: 10.1080/13548509808400610

LaBrie, J., Earleywine, M., Schiffman, J., Pedersen, E., \& Marriot, C. (2005). Effects of alcohol, expectancies, and partner type on condom use in college males: Event-level analyses. The Journal of Sex Research, 42(3), 259-266. doi:10.1080/00224490509552280

MacDonald, T. K., \& Martineau, A. M. (2002). Self-esteem, mood, and intentions to use condoms: When does low self-esteem lead to risky health behaviors? Journal of Experimental Social Psychology, 38, 299-306. doi:10.1006/jesp.2001.1505

McCree, D. H., Wingood, G. M., DiClemente, R., Davies, S., \& Harrington, K. F. (2003). Religiosity and risky sexual behavior in African-American adolescent females. Journal of Adolescent Health, 33(1), 2-8. doi:10.1016/S1054-139X(02)00460-3

Mercer, C. H., Copas, A. J., Sonnenberg, P., Johnson, A. M., McManus, S., Erens, B., \& Cassel, J. A. (2009). Who has sex with whom? Characteristics of heterosexual partnerships reported in a national probability survey and implications for STI risk. International Journal of Epidemiology, 38(1), 206214. doi: 10.1093/ije/dyn216

Muñoz-Silva, A., Sánchez-García, M., Nunes, C., \& Martins, A. (2007). Gender differences in condom use prediction with Theory of Reasoned Action and Planned Behaviour: The role of self-efficacy and control. AIDS Care, 19(9), 1177-1181. doi: 10.1080/09540120701402772
Noar, S. M. \& Zimmerman, R. S. (2005). Knowledge regarding health behaviors: Are we moving in the right direction? Health Education Research: Theory \& Practice, 20(3), 275-290. doi: 10.1093/her/cyg113

Shearer, C. L., Hosterman, S. J., Gillen, M. M., \& Lefkowitz, E. S. (2005). Are traditional gender roles associated with risky sexual behavior and condom-related beliefs? Sex Roles, 52(56), 311-324. doi:10.1007/s11199-005-2675-4

Sheeran, P., \& Orbell, S. (1998). Do intentions predict condom use? Meta-analysis and examination of six moderator variables. British Journal of Social Psychology, 37, 231-250. doi: 10.1111/j.2044-8309.1998.tb01167.x

Snell, W. E. (1998). Sexual risk behavior beliefs and self-efficacy scales. In G. Davis, W. Yarber, R. Bauserman, G. Schreer, \& $\mathrm{S}$. Davis (Eds), Handbook of sexuality related measures (pp. 521-524). California: Sage Publications.

Sunmola, A.M. (2005). Evaluating the sexual behaviour, barriers to condom use and its actual use by university students in Nigeria. AIDS Care, 17(4), 457-465. doi:10.1080/09540120 412331319732

Thorburn, S., Harvey, S.M., \& Ryan, E.A. (2005). HIV prevention heuristics and condom use among African-Americans at risk for HIV. AIDS Care, 17(3), 335-344. doi:10.1080/09540120 412331299762

Visser, R. O., \& Smith, A. M. A. (1999). Predictors of heterosexual condom use: Characteristics of the situation are more important than characteristics of the individual. Psychology, Health \& Medicine, 4(3), 265-279. doi:10.1080/135485099106207

Visser, R.O., \& Smith, A.M.A. (2001). Inconsistent users of condoms: A Challenge to traditional models of health behaviour. Psychology, Health \& Medicine, 6(1), 41-46. doi: 10.1080/13548500123746

Walsh, J. L., Fielder, R. L., Carey, K. B., \& Carey, M. P. (2013). Do alcohol and marijuana use decrease the probability of condom use for college women? The Journal of Sex Research, 51(2), 145-158. doi: 10.1080/00224499.2013.821442

Weinstein, N. D. (2007). Misleading tests of health behavior theories. Annals of Behavioral Medicine, 33(1), 1-10. doi: 10.1207/s15324796abm3301_1 